Penggunaan Ruas Jalan sebagai Pasar Tradisional di Gang Baru Pecinan, Semarang

\title{
PENGGUNAAN RUAS JALAN SEBAGAI PASAR TRADISIONAL DI GANG BARU PECINAN, SEMARANG
}

\author{
Titien Woro Murtini ${ }^{*}$, Sri Hartuti Wahyuningrum *) \\ ${ }^{*}$ Departemen Arsitektur Fakultas Teknik, Universitas Diponegoro Semarang \\ Jl. Prof. Sudarto SH Tembalang Semarang 50131
}

\begin{abstract}
Abstrak
Pemanfaatan ruas jalan gang baru sebagai ruang untuk pasar tradisional sangat menarik untuk di kaji , karena kegiatan tersebut sudah terjadi sejak masa lalu hingga sekarang, walaupun fasilitas perbelanjaan modern saat ini di kota Semarang sudah tersedia dengan kondisi yang memadahi dan nyaman namun keberadaan pasar tradisional termasuk gang baru hingga saat ini masih tetap berlangsung dan diminati oleh masyarakat tidak hanya masyarakat disekitar Pecinan saja tetapi oleh masyarakat Semarang secara keseluruhan.Penelitian Penggunaan Ruas Jalan Sebagai Pasar Tradisional di Gang Baru Pecinan Semarang bertujuan menggali faktor-faktor yang menyebabkan pasar ini masih diminati hingga saat ini dan untuk mengetahui elemen ruang apakah yang membentuk ruas gang baru menjadi pasar tradisional. Penelitian ini menggunakan metode pendekatan rasionalistik dengan paradigma kualitatif. Pendekatan penelitian rasionalistik kualitatif ini sesuai dengan sifat masalah penelitian yaitu untuk mengungkap dan memahami faktor pendorong pembentukan ruas jalan lingkungan menjadi ruang ekonomi yang berpengaruh terhadap pembentukkan karakter di Kawasan Pecinan Semarang dan faktor yang menyebabkan ruang ekonomi itu tetap bertahan hingga sekarang.
\end{abstract}

Kata Kunci : Ruang, Ruas Jalan, Aktivitas

\section{Pendahuluan}

Pasar Gang Baru terletak terletak disebuah gang atau lorong ditengah- tengah wilayah pecinan, yaitu di Jl. Gang Baru, kawasan Pecinan, Kota Semarang. Pasar Gang Baru merupakan salah satu pasar tradisional yang usianya cukup tua dan dikenal sangat lengkap walaupun tidak seluas Pasar Johar ataupun Pasar Bulu.

Aktivitas di pasar ini dimulai jam 6 hingga jam 10 pagi, setelah lewat jam tersebut pedagang sudah meninggalkan pasar sehingga pasar mulai lengang. Pasar ini sebenarnya buka hingga sore hari, tapi hanya pedagang yang tinggal di Gang Baru yang menjual bahan-bahan makanan dan obat-obatan tradisional, pakaian, hingga perlengkapan upacara ritual masyarakat Tionghoa. Pada malam hari, gang ini tidak ubahnya seperti gang - gang lain yang banyak terdapat di Pecinan Semarang.

Ruas jalan Gang Baru ini menarik untuk dikaji karena secara fisik merupakan perkampungan padat dengan bangunan khas (Tionghoa) dan bangunan klenteng, yang kehidupan sehari-harinya dipenuhi aktivitas yang luar biasa, baik ekonomi maupun budaya serta upacara- upacara adat sehingga dapat dikatakan memiliki potensi yang bersifat tangibles dan intangibles. Potensi tangibles dapat berupa peninggalan-peninggalan Cina yang secara fisik masih bisa dinikmati secara visual. Sedangkan potensi intangibles pada wilayah ini dapat berupa sejarah, budaya dan gaya hidup di permukiman pecinan.

Kawasan ini merupakan kawasan potensial sebagai kawasan yang memiliki seting budaya (aktrasi, ritual tradisi/adat masyarakat) dan setting fisik yang spesifik serta struktur tata ruang arsitektur lingkungan. Sedangkan perkembangan perencanaan kota menunjukkan kepedulian terhadap upaya konservasi dan rehabilitasi kawasan-kawasan bersejarah dalam upaya perlindungan warisan arsitektur yang berada di kawasan- kawasan tersebut. Metodologi

Pendekatan penelitian yang digunakan pada studi ini adalah dengan terjun ke lapangan secara langsung untuk mengamati aktivitas yang berlangsung di Pasar Gang Baru.

Landasan studi mengenai penggunaan ruas jalan sebagai pasar tradisional dilakukan melalui studi literatur mengenai teori-teori dan konsep-konsep yang berkaitan dengan hal tersebut. Pengumpulan data dilakukan melalui survey dan wawancara, yang hasilnya kemudian diolah dan dianalisis secara deskriptif.

\section{Kajian Kepustakaan}

1. Fasilitas Umum Kota 
Penggunaan Ruas Jalan sebagai Pasar Tradisional di Gang Baru Pecinan, Semarang

Berdasarkan Pedoman Standar Pelayanan Minimal Bidang Penataan Ruang, Perumahan dan Permukiman dan Pekerjaan Umum (Keputusan Menteri Permukiman dan Prasarana Wilayah No. 534/KPTS/M/2001) menetapkan bahwa sarana lingkungan berupa sarana niaga dengan indikator tingkat ketersediaan kebutuhan primer dan sekunder ditetapkan bahwa minimal tersedia satu pasar yang mudah diakses untuk setiap 30.000 penduduk.

\section{Linkage}

Menurut Zahnd (1999), Linkage membahas mengenai hubungan sebuah tempat dengan tempat yang lain, yang memperhatikan dan menegaskan hubungan-hubungan dan gerakan-gerakan sebuah tata ruang perkotaan. Linkage memiliki peran untuk menyatukan aktivitas. Linkage dapat dibedakan menjadi tiga, antara lain :

- Linkage visual

- Linkage structural

- $\quad$ Linkage sebagai bentuk yang kolektif

\section{Ruang Publik Kota}

Ruang publik kota merupakan salah satu elemen kota memiliki peranan untuk turut memberikan karakter tersendiri dan pada umumnya memiliki fungsi interaksi sosial bagi masyarakat, tempat berlangsungnya kegiatan ekonomi rakyat, serta tempat apresiasi budaya (Darmawan, 2009).

\section{Koridor}

Koridor merupakan elemen yang dibentuk dari dua deretan massa yang membentuk sebuah ruang (Zahnd, 1999). Menurut Krier (1996), koridor merupakan sebuah jalan yang diapit oleh dinding di sisi kiri dan kanan yang membentuk ruang-ruang di sekitar jalan. Sedangkan jalan dianggap sebagai area yang menghubungkan satu titik dengan titik yang lain dengan fungsi yang saling terkait. Sedangkan menurut Spreiregen (1965), koridor merupakan salah satu komponen perkotaan dengan bentuk linear yang tertutup di kedua sisinya namun dipersatukan oleh dinding-dinding di sekitarnya.

\section{Pasar}

Menurut Kamus Besar Bahasa Indonesia, pasar merupakan tempat untuk berjual beli. Secara garis besar pengguna pasar dapat dibedakan menjadi dua, yaitu pembeli dan pedagang. Menurut Darmawan (2009), pasar merupakan ruang terbuka atau ruas jalan yang dipergunakan untuk transaksi dan kegiatan jualbeli, biasanya bersifat temporer atau pada hari tertentu. Menurut Adhi Moersid (1995), dengan mengamati pasar dapat diketahui budaya masyarakat setempat, antara lain :

- Menu makanan sehari-hari di daerah itu

- Hasil bumi yang dihasilkan di hinterland kota itu
- Bagaimana orang berinteraksi

- Cara orang-orang berpakaian

- Tingkat disiplin warga

- Tingkat-tingkat bahasa yang dipakai dan banyak hal lagi yang dapat dijumpai di pasar.

Pasar memiliki karakteristik tersendiri yang membuat pasar yang satu berbeda dengan pasar lainnya. Menurut Rizon (1997), pasar dapat dikategorikan berdasarkan :

- Skala transaksi (the scale of transaction)

- Tipe komoditas (type of comodity)

- $\quad$ Sistem pengelolaannya (administration)

- Periodisasi (periodicity)

- Waktu operasi (nature of growth)

- Kepemilikan tanah dan bangunannya (ownership of land and building)

\section{Shared Space}

Ruang bersama, ruang berbagi bersama, atau disebut juga shared space merupakan ruang yang mewadahi interaksi antar penduduk dalam suatu komunitas, wadah untuk menampung berbagai kegiatan bersama masyarakat dalam memenuhi kebutuhan ekonomi, sosial, dan budaya warganya (Darmiwati, dalam Indeswari dkk, 2013). Ruang bersama merupakan ruang yang ada pada masyarakat, merupakan simbol bahwa masyarakat memiliki hubungan sosial yang baik, ditandai dengan adanya kebersamaan dan keguyuban. Ruang bersama terbentuk menyesuaikan dengan latar lingkungan dan budaya dalam suatu masyarakat (Indeswari dkk, 2013).

\section{Hasil Temuan dan Pembahasan}

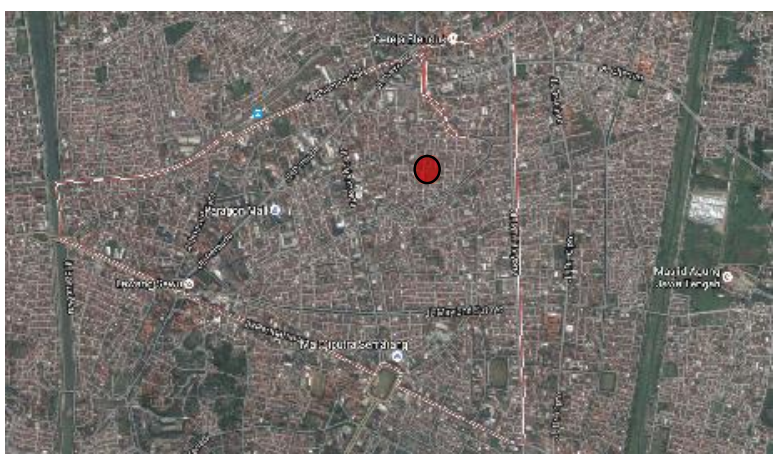

Berdasarkan Kebijaksanaan Bagian Wilayah Kota yang ada dalam RTRW Kota Semarang, maka kedudukan BWK I dalam konstelasi Kota Semarang adalah sebagai kawasan perdagangan dan jasa di pusat kota. 


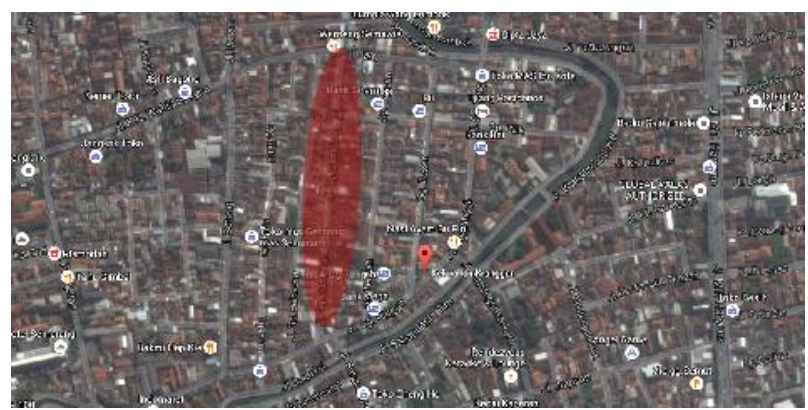

Penggunaan ruang Gang Baru yang sangat terasa adalah penggunaan untuk perdagangan, hingga mayoritas bangunan di sepanjang Gang Baru adalah merupakan rumah toko. Selain itu terdapat pedagang kaki lima (PKL) yang menjual beraneka ragam kebutuhan pokok berderet-deret di tepi, bahkan di tengah jalan pada bagian ruang yang cukup lebar. Hal ini cenderung mempersempit gerakan pemakai ruang. Ruang jalan dipenuhi oleh pedagang yang mangkal tetap maupun pedagang keliling, pedagang dan pembeli yang melakukan transaksi, serta lalu lalang orang yang sekedar lewat atau melihat-lihat maupun para penghuni yang duduk-duduk di depan rumah/tokonya.

Dengan adanya deretan atap terpal/layar dan payung yang disangga tiang-tiang yang dipasang pada serambi depan tokonya maupun pedagangpedagang informal/kaki lima di sepanjang jalan ini walaupun tidak teratur turut menciptakan Enclosure ruang yang tidak langsung juga membagi ruangan menjadi ruang-ruang wilayah kekuasaan para penjual masing-masing.

Setelah jam pasar berakhir, fungsi hunian dapat dirasakan kembali. Jalan berubah menjadi ruang sosialisasi warga dan kendaraan kembali dapat melewati jalan ini. Namun aktifivitas pasar meninggalkan kesan visual yang tidak nyaman, berupa tumpukan meja, bangku-bangku, dan bendabenda lain yang dipakai sebagai sarana berjualan PKL.

Pasar Gang Baru merupakan pasar tradisional yang menyediakan menu makanan sehari-hari, baik makanan basah maupun makanan kering, buah dan sayuran, keperluan sandang, hingga keperluan untuk sembahyang. Pasar merupakan tempat bertemunya $\mathrm{p}$ edagang dan pembeli, seperti pasar tradisional pada umumnya, di pasar Gang Baru juga terjadi aktivitas tawar menawar.

Meskipun sekarang berkembang supermarketsupermarket serta minimarket-minimarket yang semakin banyak dan mudah dijangkau, tetapi keberminatan masyarakat akan Pasar Gang Baru masih tinggi. Hal ini dapat dilihat dari pembeli yang datang ke pasar Gang Baru tidak hanya masyarakat di kawasan sekitar pecinan, tetapi masyarakat dari berbagai daerah di seputar kota Semarang. Alasan masyarakat berminat untuk berbelanja di Pasar Gang Baru adalah karena pasar ini menawarkan barang dagangan dengan kualitas yang baik.
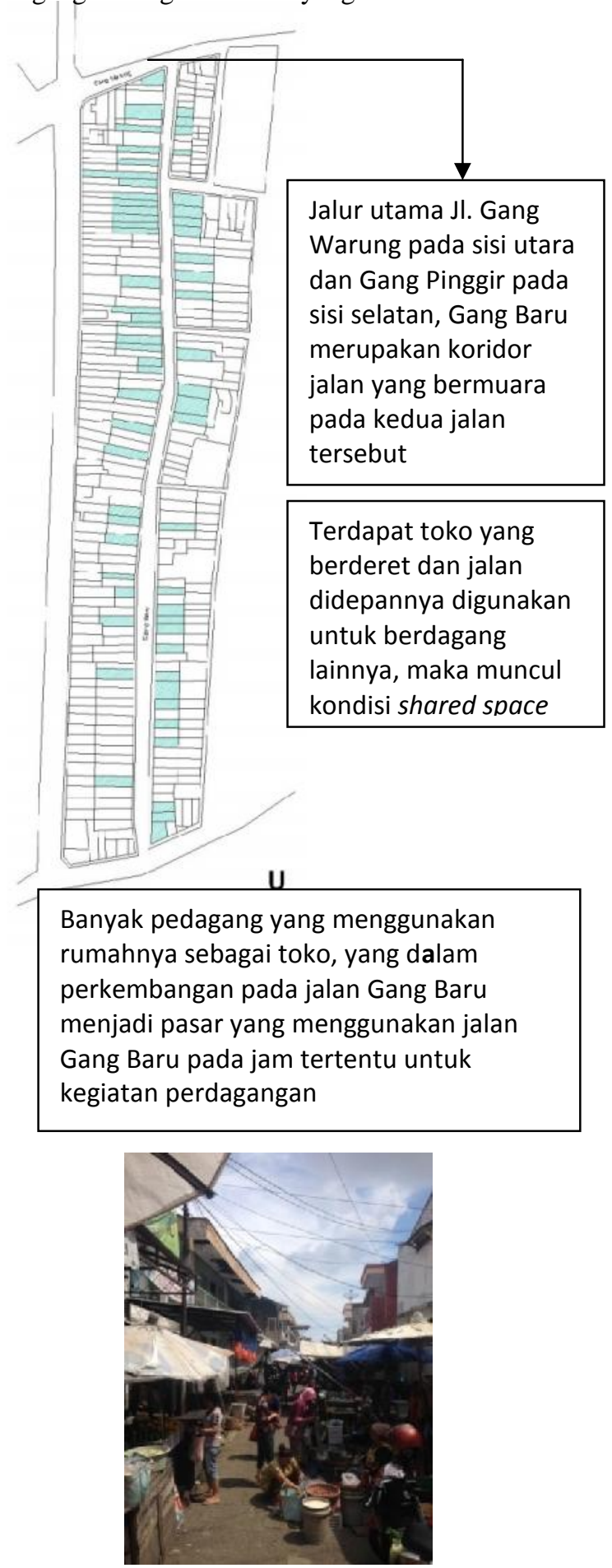

Kegiatan Perdagangan di Pasar Gang Baru Sumber : Dokumentasi Pribadi 
Penggunaan Ruas Jalan sebagai Pasar Tradisional di Gang Baru Pecinan, Semarang

Ruang pasar yang ada di Gang Baru tidak seperti pasar modern yang terdapat zonasi-zonasi yang jelas. Pasar Gang Baru terdapat tiga segmen, yang masing-masing segmennya cukup variatif dan lengkap tipe komoditas yang dijual.

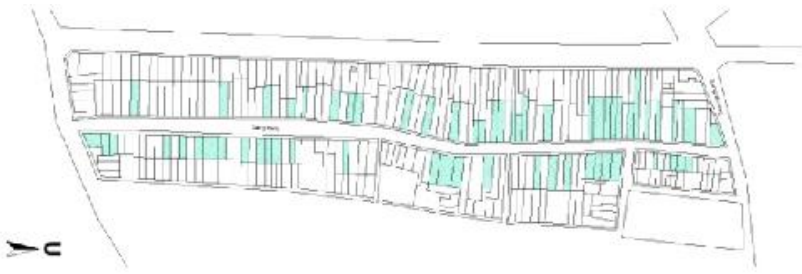

Pasar Gang Baru ini ada sudah cukup lama. Pasar Gang Baru beroperasi mulai dari jam 06.00-13.00 namun jam yang paling padat adalah pada jam 07.0009.00. Hal ini diawali dari penduduk setempat yang menjadikan rumahnya sebagai rumah usaha. Gang ini merupakan gang yang berhadapan langsung dengan klenteng dan posisi ini diyakini oleh penduduk setempat merupakan posisi yang baik untuk berdagang. Pendatang melihat adanya potensi ini dan mulai berdagang di ruas jalan tersebut, hal ini terus berlangsung hingga sekarang dan turun-temurun hingga 3 generasi.

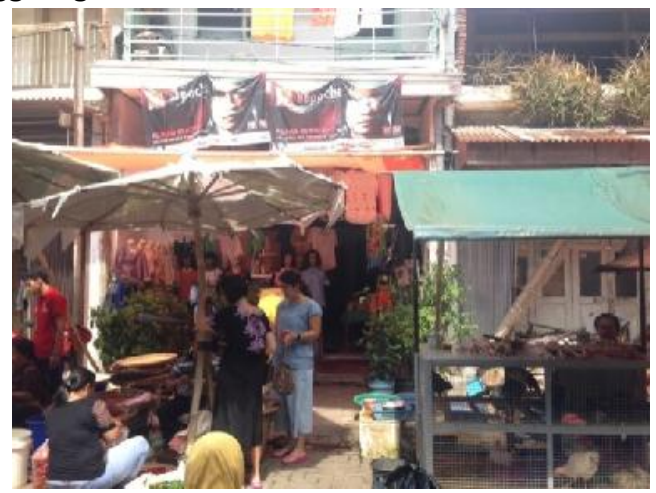

Rumah Usaha dan Pedagang Pendatang yang Berjualan di Depan Rumah

Unsur kebersamaan dengan tetap menjaga tidak saling mengganggu antar pedagang dengan pengaturan keragaman yang natural telah menghasilkan pola pasar yang unik, yaitu yang ditengarai meliputi hal-hal :

1. Ruang di depan toko bisa dimanfaatkan oleh pedagang lainnya tentunya dengan tipe pedagang dasaran yang penempatannya tidak menutupi secara menyeluruh toko di belakangnya

2. Zonasi atau kelompok pedagang dengan jenis dagangan dasaran tersebar dalam kelompok dengan batas yang tidak definitif (sporadis) : hal ini bisa membantu menyebarkan pengunjung pasar secara merata karena pada bagian tertentu sudah bisa menemui jenis dagangan yang beragam sehingga bisa melokalisir area yang dikunjungi. meskipun mengingat panjang jalan Gang baru relatif pendek jadi dapat dikunjungi dengan waktu singkat.

3. Pedagang yang mempunyai toko/ruko di Gang tersebut pada umumnya menjual bahan makanan spesifik dan rata-rata merupakan bahan makanan kering atau hasil industry seperti : bumbu kering, kerupuk, bahan roti, kulit lumpia, bahan makanan/masakan, perlengkapan dapur dan lainnya termasuk produksi sosis, bakmi dan sebagainya.

4. Sedangkan pedagang dasaran yang menempati badan jalan merupakan pedagang dengan bahan dagangan berupa bahan makanan basah seperti daging, ikan, sayur dan aneka bumbu maupun makanan lainnya yang berdagang hanya pada pagi hari sampai siang saja.

5. Pedang yang berada di depan toko secara umum selalu berbeda jenis dagangannya dengan yang dijual di toko termasuk skala dagangannya. Pedagang dasaran yang relatif besar lapaknya pada umumnya menempati bagian depan rumah yang tidak untuk berdagang atau tidak secara frontal berada di depan rumah toko.
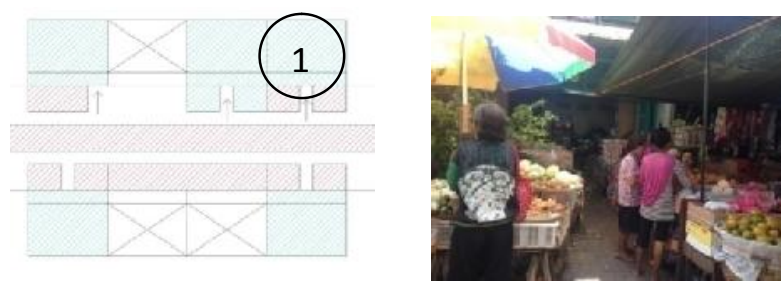

Toko di bagian depan diapit dua pedagang dasaran dengan akses jalan ke toko berada di tengah sehingga pembeli yang belanja ke toko tidak tergganggu aksesnya
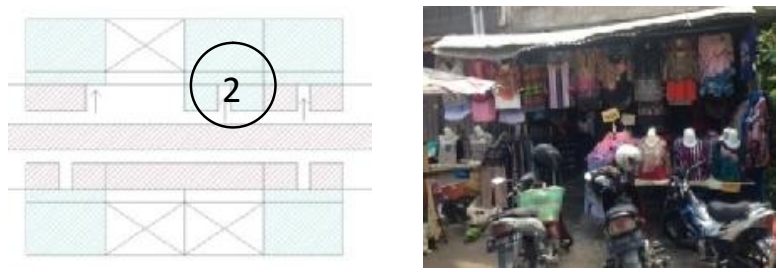

Toko di bagian depan masih bisa digunakan untuk ekstensi dagangan pedagang toko
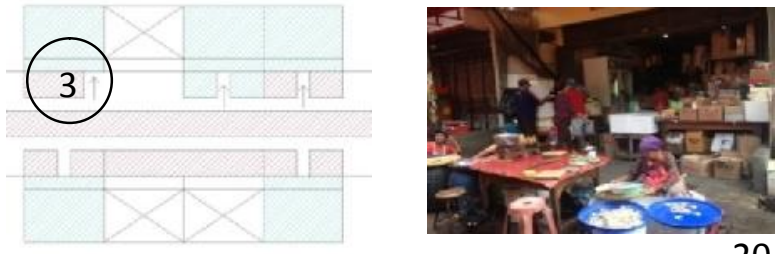
Pedagang dasaran menutup salah satu sisi toko pedagang di belakangnya, akses jalan disisakan pada salah satu sisi saja

Dari beberapa contoh tersebut di atas terlihat bahwa pola penggunaan ruang di depan toko bisa beragam tergantung dari karakteristik toko di belakangnya terhadap kebutuhan akses ke tokonya. Jenis pedagang yang berada di depannya juga beragam namun pada umumnya berbeda jenis dagangannya dengan toko di belakangnya.

Hal ini terbentuk secara natural dalam artian penggunaan ruang di depan toko merupakan bentuk kerja sama simbiose mutualisme karena pedagang toko juga diuntungkan adanya bantuan penjagaan oleh pedagang dasaran didepannya, adapaun pedagang dasaran juga bisa lebih mengkespose dagangannya saat pembeli menuju toko.

Sehingga tidak timbul persaingan yang tidak perlu dalam konteks kelompok jenis dagangan, pada umunya pembeli juga sudah mempunyai langganan masing-masing sehingga secara teknis penjualan berlangsung merata sesuai kapasitas pedangan masing-masing. Khususnya untuk jenis dagangan spesifik Produk Gang Baru tetap dapat menjadi unggulan karena memang hanya ditemui di pasar tersebut.

\section{KESIMPULAN}

- Keberadaan pasar pada kawasan permukiman adalah suatu pemenuhan kebutuhan dasar baik untuk pemenuhan kebutuhan harian Maupun kebutuhan lain yang diperlukan oleh masyarakat.

- Penggunaan ruas jalan sebagai sarana untuk berjualan di gang Baru adalah di dasari oleh pembentukan ruang oleh masyarakat penghuni kawasan Pecinan di mana ruas jalan tersebut posisinya adalah "sunduk sate" terhadap bangunan kelenteng. Dan hal ini dianggap sebagai ruang yang memiliki "hoki" bila untuk berdagang maka akan menguntungkan. Dari hal inilah maka Ruas Jalan Gang Baru di fungsikan sebagai ruang untuk berdagang baik oleh penghuni maupun oleh pedagang yang berdatangan untuk mencari keuntungan di ruas jalan tersebut.

- Penggunaan ruang yang saling berdampingan oleh penghuni maupun oleh para pedagang pendatang yang hanya non permanen (Oprokan) adalah satu rumah yang merupakan kesepakan antar mereka tanpa ada pungutan biaya, kesepakatan tersebut hanya antar mereka saja bahwa pedagang pendatang mau untuk membersihkan halaman depan dari salah rumah yang ditempati oleh pedagang oprokan tersebut. Ini adalah perwujudan dari konsep "shared space".

- Pasar gang baru sampai dengan saat sekarang ini masih eksis keberadaannya dan masih diminati oleh pembeli yang datang dari berbagai kawasan di kota Semarang, walaupun keberadaan pasar tersebut memiliki daya jangkau yang termasuk tidak menguntungkan karena tidak adanya fasilitas transportasi umum yang melewati kawasan tersebut, hal ini disebabkan karena kualitas dagangan di pasar tersebut lebih baik dari pada pasar yang lain hal ini di sebabkan karena kesepakatan dari para pedagang untuk menjaga kualitas dagangan dan kesepakatan untuk memberikan pelayanan yang baik kepada para pembeli.

\section{Rekomendasi}

Keberadaan pasar gang baru yang masih eksis hingga sekarang maka hal ini hendaknya menjadi perhatian bagi pemerintah untuk memperhatikan ruang pasar ini agar menjadi salah satu daya tarik dari kawasan dengan mengupayakan beberapa hal antara lain :

1. Pemeliharaan terhadap kebersihan yang lebih baik.

2. Pengaturan terhadap tata ruang ruas jalan agar sesuai dengan fungsi ganda yang terjadi di ruas jalan tersebut.

3. Penyediaan kantong-kantong parkir yang memadai sehingga tidak menimbulkan kemacetan di jalur jalan dilingkungan pecinan.

\section{DAFTAR PUSTAKA}

Darmawan, Edy. 2009. Ruang Publik dalam Arsitektur Kota. Semarang : Badan Penerbit Universitas Diponegoro.

Indeswari, Ayu, Antariksa, Galih Widjil Pangarsa, dan Lisa Wulandari. 2013. Pola Ruang Bersama pada Permukiman Madura Medalungan di Dusun Baran Randugading. Jurnal RUAS. Vol. 11 No. 1, Juni 2013.

Zahnd, Markus. 1999. Perancangan Kota Secara Terpadu. Yogyakarta : Kanisius. 